\author{
Marquette University \\ e-Publications@Marquette
}

\title{
$5-2015$
}

\section{Job Displacement's Long-run Effect on Access to Employer- provided Health Insurance and Other Fringe Benefits}

Nicholas A. Jolly

Marquette University, nicholas.jolly@marquette.edu

Brian J. Phelan

DePaul University

Follow this and additional works at: https://epublications.marquette.edu/econ_fac

Part of the Economics Commons

\section{Recommended Citation}

Jolly, Nicholas A. and Phelan, Brian J., "Job Displacement's Long-run Effect on Access to Employerprovided Health Insurance and Other Fringe Benefits" (2015). Economics Faculty Research and Publications. 508.

https://epublications.marquette.edu/econ_fac/508 
Marquette University

e-Publications@Marquette

\section{Economics Faculty Research and Publications/College of Business Administration}

This paper is NOT THE PUBLISHED VERSION; but the author's final, peer-reviewed manuscript. The published version may be accessed by following the link in the citation below.

Economics Letters, Vol. 130 (May 2015): 100-104. DOI. This article is (C) Elsevier and permission has been granted for this version to appear in e-Publications@Marquette. Elsevier does not grant permission for this article to be further copied/distributed or hosted elsewhere without the express permission from Elsevier.

\section{Job Displacement's Long-Run Effect on Access to Employer-Provided Health Insurance and Other Fringe Benefits}

Nicholas A. Jolly

Marquette University, PO Box 1881, Milwaukee, WI

Brian J. Phelan

DePaul University, 1 E. Jackson Blvd, Suite 6200, Chicago, IL

\section{Abstract}

This paper investigates the effect of job displacement on access to employer-provided fringe benefits. We find that displacement is associated with lost access to all seven employer-provided benefits investigated. These losses increase the cost of displacement by $10 \%$ per year.

Keywords

Job displacement, Health insurance, Fringe benefits 


\section{Introduction}

This paper investigates job displacement's long-term effects on access to employer-provided health insurance and other fringe benefits using data from the National Longitudinal Survey of Youth 1979 (NLSY79). Previous research typically focuses on the earnings effects of these exogenous job losses. The literature routinely finds that displaced workers experience large and persistent earnings losses relative to their non-displaced peers. ${ }^{2}$ These losses, however, provide a lower bound of the costs associated with this life event. Other studies document deleterious health effects of displacement and short-term losses in access to employer-provided health insurance. ${ }^{3}$

This paper contributes to the literature in three ways. First, we examine displacement's long-term effect on the probability of having access to employer-provided health insurance, which none of the earlier literature has done. Second, we are the first to study job displacement's long-term effect on the probability of having access to other employer-provided benefits including: life insurance, dental insurance, paid sick leave, paid vacation, employer-provided training, and retirement benefits. Third, we monetize this lost access to fringe benefits and compare this value to the estimated earnings losses.

\section{Data}

The data for this analysis come from the core representative sample of the NLSY79, which is a cohort-based panel of 6111 individuals aged 14-21 as of December 31, 1978. It is common in the displacement literature to focus on workers with significant attachment to the labor force. Thus, the analysis excludes never-employed individuals, career part-time workers (those averaging less than 30 hours per week over the panel), and nondisplaced individuals who were not employed during seven or more surveys since completing their schooling. We also exclude those who attritted before 1990, individuals who responded to fewer than 12 of the 22 surveys during our period of analysis (1979-2006), and respondents with missing information on education, Armed Forces Qualifying Test (AFQT) scores, or age.

Displacement is defined as an involuntary job loss due to a layoff or plant closure of a worker with at least three years of tenure on the lost job. ${ }^{4}$ The analysis follows a worker's first displacement after the age of 24 because subsequent job losses may not be exogenous (Stevens, 1997). Therefore, individuals with less than three years of tenure at the time of their first job loss are not eligible to enter the displaced sample if they experience a subsequent job loss. These workers are removed from the analysis. ${ }^{5}$ Summary statistics on the 521 individuals in the displaced (i.e. treatment) sample and the 2705 individuals in the non-displaced (i.e. control) sample are in Table 1. Overall, the displaced and non-displaced samples are similar. However, displaced workers are more likely to be African American and less likely to be union members. They also have less education and lower AFQT scores.

Table 1. Descriptive statistics by displacement status.

\begin{tabular}{|l|l|l|}
\hline & Non-displaced & Displaced \\
\hline Age & 34.8 & 35.2 \\
\hline Female & 45.8 & 43.8 \\
\hline African American & 10.0 & 12.5 \\
\hline Years of education & 13.9 & 13.1 \\
\hline AFQT percentile & 54.5 & 46.2 \\
\hline Years of firm tenure & 8.4 & 7.8 \\
\hline Union status & 12.7 & 11.1 \\
\hline
\end{tabular}


Notes: For displaced workers, statistics are calculated during the year before separation. For the non-displaced group, all person-year observations when an individual is age $25+$ and has three years firm-level tenure are used. All values are mean values.

The employer-provided benefits data come from a series of annual questions in the NLSY79 about access to fringe benefits. ${ }^{6}$ Table 2 presents summary statistics on earnings and the prevalence of these benefits for the displaced and non-displaced samples over the pre- and post-job loss periods. ${ }^{7}$ Average earnings and access to these employer-provided benefits are similar in the "pre-displacement" period. However, the groups experience different changes in earnings and in the availability of fringe benefits from the "pre-displacement" period to the "post-displacement" period. For fringe benefits, we generally observe decreasing availability among the displaced and increasing availability among the non-displaced. The difference-in-differences from these summary statistics suggest that displaced workers experience relative losses in fringe benefits ranging from 512 percentage points.

Table 2. Access to employer-provided benefits before and after displacement.

\begin{tabular}{|l|l|l|l|l|l|l|l|}
\hline & $\begin{array}{l}\text { Pre- } \\
\text { Disp. }\end{array}$ & $\begin{array}{l}\text { Post- } \\
\text { Disp. }\end{array}$ & Difference & & $\begin{array}{l}\text { Pre- } \\
\text { Disp. }\end{array}$ & $\begin{array}{l}\text { Post- } \\
\text { Disp. }\end{array}$ & Difference \\
\hline Real earnings & & & & $\begin{array}{l}\text { Health } \\
\text { insurance }\end{array}$ & & & \\
\hline Displaced & 28,650 & 35,588 & 6,938 & Displaced & 0.786 & 0.755 & -0.031 \\
\hline Non-displaced & 28,758 & 43,608 & 14,850 & Non-displaced & 0.752 & 0.810 & 0.058 \\
\hline Difference & & & $-\$ 7,912$ & Difference & & & -0.089 \\
\hline Life insurance & & & & $\begin{array}{l}\text { Dental } \\
\text { insurance }\end{array}$ & & & \\
\hline Displaced & 0.666 & 0.652 & -0.014 & Displaced & 0.560 & 0.614 & 0.054 \\
\hline Non-displaced & 0.641 & 0.715 & 0.074 & Non-displaced & 0.549 & 0.655 & 0.106 \\
\hline Difference & & & -0.088 & Difference & & & -0.052 \\
\hline Paid vacation & & & & Paid sick time & & & \\
\hline Displaced & 0.817 & 0.749 & -0.068 & Displaced & 0.601 & 0.531 & -0.070 \\
\hline Non-displaced & 0.774 & 0.801 & 0.027 & Non-displaced & 0.631 & 0.684 & 0.053 \\
\hline Difference & & & -0.095 & Difference & & & -0.123 \\
\hline $\begin{array}{l}\text { Retirement } \\
\text { benefits }\end{array}$ & & & & $\begin{array}{l}\text { Employer } \\
\text { training }\end{array}$ & & & \\
\hline Displaced & 0.600 & 0.612 & 0.012 & Displaced & 0.480 & 0.454 & -0.026 \\
\hline Non-displaced & 0.588 & 0.710 & 0.122 & Non-displaced & 0.500 & 0.579 & 0.079 \\
\hline Difference & & & -0.110 & Difference & & & -0.105 \\
\hline
\end{tabular}

Notes: Entries for earnings are in 2006 dollars. Entries for fringe benefits indicate proportions. For displaced and non-displaced workers, the entries in the Pre-Displacement column use all pre-separation observations (including periods of non-employment). Similarly, entries in the Post-Displacement column use all postseparation observations (including periods of non-employment). For the non-displaced group, the year of "displacement" corresponds to a randomly chosen year such that the distribution of "displacements" assigned to each year matches the distribution in the displaced sample.

\section{Methodology}

The empirical methodology follows past studies in the displacement literature and uses an event study framework to estimate displacement's impact on various outcomes: 
(1) $y_{i t}=\alpha_{i}+\gamma_{t}+X_{i t}^{\prime} \beta+\sum_{k=-2}^{10} D_{i t}^{k} \delta_{k}+\epsilon_{i t}$.

Typically, $y_{i t}$ equals the real labor earnings for individual $\mathrm{i}$ in year $\mathrm{t}$. In this analysis, $y_{i t}$ also equals a series of seven dummy variables, one for each of the employer-provided benefits, equaling one if individual $i$ in year $t$ has access to the benefit through their own employment. Eq. (1), which is estimated as a linear probability model for the benefit specifications, includes individual fixed-effects $\left(\alpha_{i}\right)$, a set of year dummy variables $\left(\gamma_{t}\right)$, and a quadratic in age $\left(X_{i t}\right)$. Finally, $D_{i t}^{k}$ is a series of dummy variables equaling one if individual $i$ experiences a displacement in year $t$, where $k$ indexes these variables from two years before job loss to ten years afterward. The results focus on even-numbered post-displacement years because the NLSY79 became a biennial survey in 1994. Therefore, anyone displaced from 1994 onwards is only observed in evennumbered post-displacement years. Additionally, individuals displaced in odd years just prior to 1994 are only observed in odd-numbered post-displacement years. For example, someone displaced in 1993 is not observed in the second year after job loss (1995), but is observed in the first year after job loss (1994), the third year after job loss (1996), etc. To maximize sample sizes in the even years, we assign these odd-year post-separation observations to even years when even post-displacement periods are missing. Continuing with the above example of an individual displaced in 1993, 1994 becomes the second year after displacement, 1996 becomes the fourth year after displacement, etc. ${ }^{8}$

\section{Results}

Table 3 presents results from Eq. (1). These results include the effects of periods of non-employment, which are common after displacement. However, the results are very similar if we exclude observations during periods of non-employment or very low earnings (see Table A.2 in Appendix). Therefore, the estimates largely reflect the conditions at new jobs following displacement. 
Table 3. Displacement's impact on earnings and employer-provided benefits.

\begin{tabular}{|c|c|c|c|c|c|c|c|c|}
\hline & Real earnings & $\begin{array}{l}\text { Health } \\
\text { insurance }\end{array}$ & Life insurance & $\begin{array}{l}\text { Dental } \\
\text { insurance }\end{array}$ & $\begin{array}{l}\text { Paid } \\
\text { vacation }\end{array}$ & $\begin{array}{l}\text { Paid sick } \\
\text { time }\end{array}$ & $\begin{array}{l}\text { Retirement } \\
\text { benefits }\end{array}$ & $\begin{array}{l}\text { Employer } \\
\text { training }\end{array}$ \\
\hline \multirow[t]{2}{*}{2 years before } & -2806 & 0.024 & 0.027 & 0.022 & $0.046^{* * *}$ & $0.044^{* *}$ & -0.013 & -0.011 \\
\hline & (2214) & $(0.02)$ & $(0.02)$ & $(0.02)$ & $(0.01)$ & $(0.02)$ & $(0.02)$ & $(0.02)$ \\
\hline \multirow[t]{2}{*}{ Year of } & $-13,360^{* * *}$ & $-0.151^{* * *}$ & $-0.167^{* * *}$ & $-0.123^{* * *}$ & $-0.165^{* * *}$ & $-0.088^{* * *}$ & $-0.139 * * *$ & $-0.104^{* * *}$ \\
\hline & $(1853)$ & $(0.02)$ & $(0.03)$ & $(0.03)$ & $(0.02)$ & $(0.03)$ & $(0.03)$ & $(0.03)$ \\
\hline \multirow[t]{2}{*}{2 years after } & $-10,990^{* * *}$ & $-0.073^{* * *}$ & $-0.099 * * *$ & -0.043 & $-0.085^{* * *}$ & $-0.047^{*}$ & $-0.057^{*}$ & $-0.092^{* * *}$ \\
\hline & $(1504)$ & $(0.02)$ & $(0.02)$ & $(0.03)$ & $(0.02)$ & $(0.03)$ & $(0.03)$ & $(0.03)$ \\
\hline \multirow[t]{2}{*}{4 years after } & $-12,378^{* * *}$ & $-0.114^{* * *}$ & $-0.120^{* * *}$ & $-0.069^{* *}$ & $-0.094^{* * *}$ & -0.050 & $-0.066^{* *}$ & -0.047 \\
\hline & (2369) & $(0.02)$ & $(0.03)$ & $(0.03)$ & $(0.02)$ & $(0.03)$ & $(0.03)$ & $(0.03)$ \\
\hline \multirow[t]{2}{*}{6 years after } & $-10,345^{* * *}$ & $-0.104^{* * *}$ & $-0.087^{* * *}$ & -0.047 & $-0.055^{* *}$ & $-0.099 * * *$ & $-0.064^{*}$ & -0.038 \\
\hline & $(2540)$ & $(0.03)$ & $(0.03)$ & $(0.03)$ & $(0.02)$ & $(0.03)$ & $(0.04)$ & $(0.04)$ \\
\hline \multirow[t]{2}{*}{8 years after } & $-12,810^{* * *}$ & $-0.132^{* * *}$ & $-0.111^{* * *}$ & -0.051 & $-0.052^{* *}$ & -0.024 & -0.045 & $-0.060^{*}$ \\
\hline & $(3132)$ & $(0.03)$ & $(0.03)$ & $(0.03)$ & $(0.03)$ & $(0.04)$ & $(0.03)$ & $(0.04)$ \\
\hline \multirow[t]{2}{*}{10 years after } & $-11,538^{* * *}$ & $-0.133^{* * *}$ & $-0.116^{* * *}$ & $-0.074^{* *}$ & $-0.083^{* * *}$ & -0.057 & $-0.090^{* *}$ & $-0.064^{*}$ \\
\hline & $(2740)$ & $(0.03)$ & $(0.03)$ & $(0.04)$ & $(0.03)$ & $(0.04)$ & $(0.04)$ & $(0.04)$ \\
\hline R2 & 0.02 & 0.04 & 0.05 & 0.06 & 0.02 & 0.01 & 0.03 & 0.01 \\
\hline $\mathrm{N}$ & 57,816 & 50,532 & 50,105 & 42,933 & 49,678 & 41,455 & 35,128 & 34,878 \\
\hline
\end{tabular}

Notes: All regressions control for individual fixed effects and include a quadratic in age and dummy variables for calendar year as additional independent variables. Standard errors, which are clustered at the individual level, are shown in parentheses. Real earnings losses are in 2006 dollars.

$* p<0.1$.

$* * p<0.05$.

$* * * p<0.01$. 
We find that displacement is associated with large and persistent declines in the availability of employerprovided health insurance, life insurance, and paid vacation. The estimates show that in the immediate period following displacement, the probability that a worker has access to these benefits through their employer declines by 15-17 percentage points. These reduced probabilities persist and remain 8-13 percentage points below their non-displaced counterparts even ten years after job loss.

Displacement also affects the probability that workers have access to employer-provided dental insurance, paid sick time, retirement benefits, and employer-provided training, which includes tuition reimbursement. The estimated losses of these benefits tend to be smaller in the short-run, ranging from 9-14 percentage points, and less persistent than the losses of health- and life insurance. However, the lost access to retirement benefits, employer-provided training, and dental insurance are relatively persistent. Displaced workers are 6-9 percentage points less likely to have access to these benefits through their employer even ten years after displacement.

The remainder of the paper monetizes these losses in access to employer-provided benefits. Table 4 presents estimates of the average employer costs of offering these fringe benefits to each employee in $2006 .^{9}$ The hourly cost of offering each benefit is calculated by dividing the average cost per-worker by the share of workers eligible to receive the benefit. Data to calculate the cost of offering each benefit (except employer-provided training) come from the Employer Cost of Employee Compensation (ECEC) quarterly reports and the Employee Benefits for Private Industry 2006 report, both of which are administered by the Bureau of Labor Statistics (BLS) and based upon the National Compensation Survey. ${ }^{10}$ The data on the cost of employer training come from the BLS' 1995 Survey of Employer-Provided Training. ${ }^{11}$ 
Table 4. Employer cost per hour worked for fringe benefits-2006.

\begin{tabular}{|c|c|c|c|c|c|c|c|c|}
\hline & $\begin{array}{l}\text { Health } \\
\text { insurance }\end{array}$ & $\begin{array}{l}\text { Life } \\
\text { insurance }\end{array}$ & $\begin{array}{l}\text { Dental } \\
\text { insurance }\end{array}$ & $\begin{array}{l}\text { Paid } \\
\text { vacation }\end{array}$ & Paid sick time & $\begin{array}{l}\text { Retirement } \\
\text { benefits }\end{array}$ & & $\begin{array}{l}\text { Employer } \\
\text { training }\end{array}$ \\
\hline & & & & & & $\begin{array}{l}\text { Defined } \\
\text { benefits }\end{array}$ & $\begin{array}{l}\text { Defined } \\
\text { contribution }\end{array}$ & \\
\hline $\begin{array}{l}\text { Average hourly cost per } \\
\text { employee }\end{array}$ & $\$ 1.87$ & $\$ 0.05$ & $\$ 0.18$ & $\$ 0.89$ & $\$ 0.29$ & $\$ 0.74$ & $\$ 0.44$ & $\$ 0.21$ \\
\hline $\begin{array}{l}\text { Share of employees } \\
\text { eligible }\end{array}$ & $71 \%$ & $53 \%$ & $46 \%$ & $77 \%$ & $57 \%$ & $21 \%$ & $54 \%$ & $84 \%$ \\
\hline $\begin{array}{l}\text { Hourly cost per eligible } \\
\text { employee }\end{array}$ & $\$ 2.64$ & $\$ 0.09$ & $\$ 0.39$ & $\$ 1.16$ & $\$ 0.51$ & $\$ 3.50$ & $\$ 0.81$ & $\$ 0.25$ \\
\hline $\begin{array}{l}\text { Yearly cost per eligible } \\
\text { employee }\end{array}$ & $\$ 5280$ & $\$ 189$ & $\$ 781$ & $\$ 2312$ & $\$ 1018$ & $\$ 3127$ & & $\$ 494$ \\
\hline $\begin{array}{l}\text { Combined fringe benefit } \\
\text { costs }\end{array}$ & & & & & $\$ 13,200$ & & & \\
\hline
\end{tabular}

Notes: Data on the average cost per employee for health insurance, life insurance, dental insurance, paid sick time, paid vacation, and retirement benefits come from the 2006 National Compensation Survey (NCS) from the Bureau of Labor Statistics (BLS). These per hour costs are each presented quarterly in the Employer Cost for Employee Compensation (ECEC) news releases. However, the cost of health insurance is calculated to be $90 \%$ of the cost of health benefits and the cost of dental insurance is calculated to be $8.6 \%$ of the costs of health benefits because the health benefits figures in the ECEC include medical, dental, and vision insurance. This percentage breakdown follows the work of Lettau (2004). All entries are for the civilian workforce in all occupations. The values for the share of eligible employees come from the Employee Benefits in Private Industry report 2006. Data on the cost and share eligible for employer training come from the BLS report on Employer-Provided Formal Training in 1995. The dollar values in that report refer to employer spending per employee in 1994. Dollar amounts were converted to 2006 dollars using the Consumer Price Index for All Urban Consumers. Yearly totals assume employees work 2000 hours. For the yearly total cost for retirement benefits, we assumed $21 / 75=28 \%$ of eligibles received the defined benefit retirement plan and $54 / 75=72 \%$ received the defined contribution plan.

Multiplying the yearly dollar amounts from Table 4 by the appropriate parameter estimates from Table 3 provides an approximate dollar value to the losses of employer-provided benefits. The results are presented in Table 5 and show that the average annual value of lost fringe benefits equals $\$ 1238$. Since the average post-displacement earnings loss equals $\$ 11,903$, these lost fringe benefits increase the annual costs of displacement, over and above the estimated earnings losses, by an average of $10.4 \%$.

Table 5. The dollar value of displacement's impact on employer-provided benefits. 


\begin{tabular}{|c|c|c|c|c|c|c|c|c|c|c|}
\hline & $\begin{array}{l}\text { Real } \\
\text { earnings }\end{array}$ & $\begin{array}{l}\text { Health } \\
\text { insurance }\end{array}$ & $\begin{array}{l}\text { Life } \\
\text { insurance }\end{array}$ & $\begin{array}{l}\text { Dental } \\
\text { insurance }\end{array}$ & $\begin{array}{l}\text { Paid } \\
\text { vacation }\end{array}$ & $\begin{array}{l}\text { Paid sick } \\
\text { time }\end{array}$ & $\begin{array}{l}\text { Retirement } \\
\text { benefits }\end{array}$ & $\begin{array}{l}\text { Employer } \\
\text { training }\end{array}$ & $\begin{array}{l}\text { Total fringe } \\
\text { benefits } \\
\text { loss }\end{array}$ & $\begin{array}{l}\text { Percentage } \\
\text { increase in tota } \\
\text { loss }\end{array}$ \\
\hline Year of & 13,360 & 797 & 32 & 96 & 381 & 90 & 435 & 51 & 1882 & $14.1 \%$ \\
\hline 2 years after & 10,990 & 385 & 19 & 34 & 196 & 48 & 178 & 45 & 906 & $8.2 \%$ \\
\hline 4 years after & 12,378 & 602 & 23 & 54 & 217 & 51 & 206 & 23 & 1176 & $9.5 \%$ \\
\hline 6 years after & 10,345 & 549 & 16 & 37 & 127 & 101 & 200 & 19 & 1049 & $10.1 \%$ \\
\hline 8 years after & 12,810 & 697 & 21 & 40 & 120 & 24 & 141 & 30 & 1073 & $8.4 \%$ \\
\hline 10 years after & 11,538 & 702 & 22 & 58 & 192 & 58 & 281 & 32 & 1345 & $11.7 \%$ \\
\hline
\end{tabular}

Notes: Implied dollar losses of various employer-provided benefits are calculated by multiplying the coefficients from the regression results presented in Table 3 by the appropriate yearly totals from Table 4. All costs are in 2006 dollars. 


\section{Discussion and conclusion}

Using data from the NLSY79, this paper investigates the long-term effects of worker displacement on access to employer-provided benefits (through one's own employment). The results demonstrate that involuntary job loss has a persistent, negative effect on the probability of receiving employer-sponsored health insurance, life insurance, and paid vacation. Displacement also reduces the likelihood of receiving dental insurance, paid sick time, retirement benefits, and employer-provided training for at least the first few years following separation.

These lost fringe benefits impose additional, non-trivial costs to displaced workers that amount to a $10 \%$ increase over and above the estimated earnings losses. However, these cost estimates likely understate the realized costs to displaced workers for at least three reasons. First, worker displacement is associated with increased morbidity and mortality rates. Thus, lost employer-sponsored health insurance, dental insurance, and paid sick time may contribute directly to these documented health problems. Second, reductions in the probability of receiving formal training may contribute to the persistent earnings losses. Finally, the costs associated with these lost benefits are based upon the cost to the employer; however, the costs to the employee may be significantly larger. This is especially true for health insurance and other insurance products due to adverse selection. This may also be true for retirement plans. In a defined benefit program, displacement will be more costly to individuals because vesting often takes many years and the benefit is based upon one's highest earnings. Additionally, in a defined contribution program, several years of lost contributions could add up to even greater losses at retirement due to compounding. Thus, these cost estimates associated with lost access to employer-provided fringe benefits may reasonably be thought of as a lower bound.

\section{Acknowledgments}

We thank Kenneth A. Couch, Robert A. Moffitt, and an anonymous referee for helpful comments and suggestions. All errors are our own.

\section{Appendix.}

See Table A.1, Table A.2.

Table A.1. Description of NLSY79 fringe benefit variables.

\begin{tabular}{|l|l|l|}
\hline Fringe benefit & NLSY79 question & Years asked \\
\hline Health insurance & $\begin{array}{l}\text { Does your employer make medical, surgical, or hospital insurance } \\
\text { that covers injuries or major illnesses off the job available to you? }\end{array}$ & $1979-2006$ \\
\hline Life insurance & $\begin{array}{l}\text { Does your employer make life insurance that would cover your } \\
\text { death for reasons not connected to your job available to you? }\end{array}$ & $1979-2006$ \\
\hline Paid vacation & Does your employer make paid vacation available to you? & $1979-2006$ \\
\hline Dental insurance & Does your employer make dental benefits available to you? & $1985-2006$ \\
\hline Paid sick time & Does your employer make sick days with full pay available to you? & $1985-2006$ \\
\hline Training & $\begin{array}{l}\text { Does your employer make training or educational opportunities } \\
\text { including tuition reimbursement available to you? }\end{array}$ & $1988-2006$ \\
\hline Retirement benefits & $\begin{array}{l}\text { Does your employer make a retirement plan other than social } \\
\text { security available to you? }\end{array}$ & $1988-2006$ \\
\hline
\end{tabular}

Note: Beginning in 1994, the NLSY79 began asking these questions for up to 5 jobs. To keep things consistent with the earlier period, we simply focused on the response to the primary (\#1) job. No fringe benefit questions were asked in 1981. Fringe benefit questions continued to be asked after 2006. However, the data in this analysis does not extend beyond 2006. 
Table A.2. Displacement's impact on earnings and employer-provided benefits alternate sample.

\begin{tabular}{|l|l|l|l|l|l|l|l|l|}
\hline & $\begin{array}{l}\text { Real } \\
\text { earnings }\end{array}$ & $\begin{array}{l}\text { Health } \\
\text { insurance }\end{array}$ & $\begin{array}{l}\text { Life } \\
\text { insurance }\end{array}$ & $\begin{array}{l}\text { Dental } \\
\text { insurance }\end{array}$ & $\begin{array}{l}\text { Paid } \\
\text { vacation }\end{array}$ & $\begin{array}{l}\text { Paid sick } \\
\text { time }\end{array}$ & $\begin{array}{l}\text { Retirement } \\
\text { benefits }\end{array}$ & $\begin{array}{l}\text { Employer } \\
\text { training }\end{array}$ \\
\hline $\begin{array}{l}\text { 2 years } \\
\text { before }\end{array}$ & -2674 & -0.008 & 0.000 & -0.002 & $0.022^{*}$ & 0.025 & -0.037 & -0.033 \\
\hline & $(2073)$ & $(0.01)$ & $(0.02)$ & $(0.02)$ & $(0.01)$ & $(0.02)$ & $(0.02)$ & $(0.02)$ \\
\hline Year of & $-11,836^{* * *}$ & $-0.103^{* * *}$ & $-0.119^{* * *}$ & $-0.101^{* * *}$ & $-0.122^{* * *}$ & $-0.050^{*}$ & $-0.105^{* * *}$ & $-0.089^{* * *}$ \\
\hline & $(2183)$ & $(0.02)$ & $(0.03)$ & $(0.03)$ & $(0.02)$ & $(0.03)$ & $(0.03)$ & $(0.03)$ \\
\hline $\begin{array}{l}2 \text { years } \\
\text { after }\end{array}$ & $-10,410^{* * *}$ & $-0.042^{* *}$ & $-0.075^{* * *}$ & -0.020 & $-0.053^{* * *}$ & -0.030 & -0.037 & $-0.074^{* *}$ \\
\hline $\begin{array}{l}4 \text { years } \\
\text { after }\end{array}$ & $-11,388^{* * *}$ & $-0.094^{* * *}$ & $-0.105^{* * *}$ & $-0.070^{* *}$ & $-0.076^{* * *}$ & -0.036 & -0.043 & -0.024 \\
\hline $\begin{array}{l}6 \text { years } \\
\text { after }\end{array}$ & $-10,104^{* * *}$ & $-0.087^{* * *}$ & $-0.076^{* * *}$ & -0.042 & -0.025 & $-0.095^{* * *}$ & -0.052 & -0.024 \\
\hline $\begin{array}{l}8 \text { years } \\
\text { after }\end{array}$ & $-12,297^{* * *}$ & $-0.124^{* * *}$ & $-0.108^{* * *}$ & -0.040 & -0.037 & -0.019 & -0.048 & -0.050 \\
\hline & $(3706)$ & $(0.03)$ & $(0.03)$ & $(0.03)$ & $(0.02)$ & $(0.04)$ & $(0.04)$ & $(0.04)$ \\
\hline $\begin{array}{l}10 \\
\text { years } \\
\text { after }\end{array}$ & $-10,492^{* * *}$ & $-0.122^{* * *}$ & $-0.122^{* * *}$ & $-0.075^{* *}$ & $-0.060^{* *}$ & -0.044 & $-0.103^{* *}$ & -0.056 \\
\hline & & & & & & & $(0.03)$ & $(0.03)$ \\
\hline R2 & 0.02 & 0.03 & 0.04 & 0.07 & 0.01 & 0.01 & 0.04 & 0.01 \\
\hline $\mathrm{N}$ & 50,225 & 44,393 & 43,979 & 38,060 & 43,557 & 36,604 & 31,871 & 31,611 \\
\hline
\end{tabular}

Notes: All regressions control for individual fixed effects and include a quadratic in age and dummy variables for calendar year as additional independent variables. Standard errors, which are clustered at the individual level, are shown in parentheses. Real earnings losses are in 2006 dollars. This alternate sample excludes all periods of non-employment or when earnings are less than $\$ 3000$ per year (in 2006 dollars).

$* \mathrm{p}<0.1$.

$* * p<0.05$.

$* * * \mathrm{p}<0.01$.

\section{References}

Couch and Placzek, 2010. K.A. Couch, D.W. Placzek. Earnings losses of displaced workers revisited. Amer. Econ. Rev. (2010), pp. 572-589

Couch et al., 2013. K.A. Couch, G.L. Reznik, C.R. Tamborini, H.M. lams. Economic and health implications of long-term unemployment: earnings, disability benefits, and mortality. Res. Labor Econ., 38 (2013), pp. 259-305

Davis and Von Wachter, 2011. S.J. Davis, T. Von Wachter. Recessions and the costs of job loss. Brook. Pap. Econ. Act. (2011)

Gallo et al., 2006. W.T. Gallo, H.-M. Teng, T.A. Falba, S.V. Kasl, H.M. Krumholz, E.H. Bradley. The impact of late career job loss on myocardial infarction and stroke: a 10-year follow-up using the health and retirement survey. Occup. Environ. Med., 63 (10) (2006), pp. 683-687 
Jacobson et al., 1993. L.S. Jacobson, R.J. LaLonde, D.G. Sullivan. Earnings losses of displaced workers. Amer. Econ. Rev. (1993), pp. 685-709

Kletzer and Fairlie, 2003. L.G. Kletzer, R.W. Fairlie. The long-term costs of job displacement for young adult workers. Ind. Labor Relat. Rev. (2003), pp. 682-698

Kosteas and Renna, 2009. V.D. Kosteas, F. Renna. The impact of job displacement on employer based health insurance coverage. J. Labor Res., 30 (4) (2009), pp. 317-327

Lettau, 2004. M. Lettau. New statistics for health insurance from the national compensation survey. Mon. Labor Rev., 127 (2004), p. 46

Lin, 2005. E.Y. Lin. Health insurance coverage and reemployment outcomes among older displaced workers. Contemp. Econ. Policy, 23 (4) (2005), pp. 529-544

Podgursky and Swaim, 1987. M. Podgursky, P. Swaim. Health insurance loss: the case of the displaced worker. Mon. Labor Rev., 110 (1987), p. 30

Ruhm, 1991. C.J. Ruhm. Are workers permanently scarred by job displacements? Amer. Econ. Rev. (1991), pp. 319-324

Schaller and Stevens, 2014. Schaller, J., Stevens, A.H., 2014. Short-run effects of job loss on health conditions, health insurance, and health care utilization. Discussion Paper, National Bureau of Economic Research.

Stevens, 1997. A.H. Stevens. Persistent effects of job displacement: the importance of multiple job losses. J. Labor Econ. (1997), pp. 165-188

Strully, 2009. K.W. Strully. Job loss and health in the US labor market. Demography, 46 (2) (2009), pp. 221-246

Sullivan and Von Wachter, 2009. D. Sullivan, T. Von Wachter. Job displacement and mortality: an analysis using administrative data. Quart. J. Econ., 124 (3) (2009), pp. 1265-1306

${ }^{1}$ Tel.: +1 3123625613.

${ }^{2}$ See Ruhm (1991), Jacobson et al. (1993), Stevens (1997), Couch and Placzek (2010), and Davis and Von Wachter (2011).

${ }^{3}$ See Gallo et al. (2006), Strully (2009), Sullivan and Von Wachter (2009), Couch et al. (2013), and Schaller and Stevens (2014) for the health effects of job displacement. See Podgursky and Swaim (1987), Lin (2005), Kosteas and Renna (2009), and Schaller and Stevens (2014) for information on lost health insurance.

${ }^{4}$ This definition is standard in the literature on displacement using long survey-based panels such as the NLSY79. See Ruhm (1991), Stevens (1997), and Kletzer and Fairlie (2003).

5 Individuals can experience an involuntary job loss before age 25 and still be eligible to enter the displaced sample. Given the definition of displacement here, the analysis treats the first involuntary transition after age 24 as the initial displacement. The analysis was replicated after removing all individuals who experience their first displacement before age 25 . The results are quantitatively similar and available upon request.

${ }^{6} \mathrm{~A}$ description of the fringe benefit variables used in this analysis is presented in Table A.1.

"For non-displaced workers, the year of "displacement" is randomly assigned so that the yearly distribution of "displacements" for the control group matches the distribution of the actual displaced sample.

${ }^{8}$ Despite this adjustment, the odd year coefficients are identified from individuals displaced in the 1980s. A full set of results with the odd-year coefficients is available upon request.

${ }^{9}$ We use 2006 dollar amounts because earnings from the NLSY79 are converted to 2006 dollars.

${ }^{10}$ The 2006 ECEC quarterly reports are available at www.bls.gov/schedule/archives/ecec_nr.htm/2006, and the Employee Benefits for Private Industry Report 2006 is at www.bls.gov/ncs/ebs/sp/ebsm0004.pdf.

${ }^{11}$ This report is available at www.bls.gov/ept. 